\title{
RIFT-VALLEYS AND TROUGH-VALLEYS.
}

SIR,-Professor J. W. Gregory, the originator of the term, defines a "rift-valley" as a depression due to the sinking of a band of country between parallel faults; or, in other words, as the surface expression of a trough-fault or fault-trough. Judging by the discussion that took place on Professor S. J. Shand's paper, "A Rift-Valley in Western Persia" (Q.J.G.S., vol. Ixxv, 1919, p. 245), this definition finds fairly general acceptance.

In his admirable article on Structural Geology in the New Volumes of the Encyclopcedia Britannica, Professor Grenville Cole suggests that "trough-valley" would be a more suitable term for such structures.

It has recently been my privilege to translate and present to the Geological Society of South Africa a valuable paper ${ }^{1}$ by Dr. Werner Beetz, in which that author describes a great depression in the Namib (South-West Africa) due to the foundering of a segment of the earth's crust 185 kilometres in length and some 40 kilometres in width; the sunken area being bordered not by faults, but by great monoclinal flexures, admirably exposed owing to the almost complete absence of soil and vegetation.

Dr. Beetz described this remarkable feature as a Graben, and suggested that "rift-valley" would be a suitable translation. As, however, rifting or faulting has here played a negligible rôle that term would have been misleading. After consultation with Dr. A. W. Rogers it was accordingly decided to call it a tectonic trough or simply a trough, and its expression at the surface a troughvalley. This was before I was aware of Professor Grenville Cole's suggestion.

As to the latter, it appears desirable, now that the existence of structures such as that described above has been established, to have a specific name for them.

Would it not be better, therefore, to retain the term " rift-valley", which has won such wide popularity, for depressions of this nature, where faulting can be proved to have occurred, reserving "troughvalley" for those bounded by monoclinal folds?

Geological Survey Office, Pretoria.

Percy A. Wagner.

14th April, 1924.

\section{OBITUARY.}

\section{Grenville A. J. Cole, F.R.S.}

Professor Grenville A. J. Cole, one of the most brilliant and versatile of the school of geologists which sprang up towards the end of the last century under the inspiring influence of Professor Judd,

1 "On a Trough Valley in the Namib," Trans. Geol. Soc. South Africa, 1924, p. 1 . 